\title{
Professional and personal development of university students as an axiological resource
}

\author{
E.S. Arishina ${ }^{1 *}$, O.V. Lesher ${ }^{2}$, and L.I. Starovojtova ${ }^{3}$ \\ ${ }^{1}$ Nosov Magnitogorsk State Technical University, Magnitogorsk, Russia \\ ${ }^{2}$ Nosov Magnitogorsk State Technical University, Magnitogorsk, Russia \\ ${ }^{3}$ Russian State Social University, Moscow, Russia
}

\begin{abstract}
The article deals with the conceptual provisions of the professional and personal development of university students as an axiological resource. The review and analysis of the pedagogical theory and practice of scientific literature is carried out. The features of modern professional training of university students are revealed. The definition of the category "professional and personal development of university students" is given. The developed model of the value attitude of university students to professional activity, contributing to professional and personal development, is proposed.
\end{abstract}

\section{A problem statement}

Social transformation, due to the formation of the culture of the information society and globalization, identified both the priority of humanistic values and special requirements for the readiness of university graduates to effectively solve professional problems [1-4]. One of the most important tasks of higher education, both for the development of society as a whole and for a specific individual, is the preparation of demanded graduates with a formed value attitude to the chosen profession as a characteristic of professionalism, a necessary component of effective work in all professional spheres [5].

Scientists who pay attention to the value foundations of modern domestic and foreign education [6,7], emphasize the importance of the humanitarian component in education, which ensures the unity of continuous general cultural, social, moral and professional development of the individual, taking into account social needs and personal needs.

This circumstance requires universities to switch to considering the process of vocational training from positions that reveal the value foundations of the professional and personal development of university students, in the context of the development of axiological potential [7].

The above allows us to formulate the contradictions between:

- the demand in modern society for a productive, moral, highly qualified university graduate and the existing approaches to his professional training;

\footnotetext{
*Corresponding author: prof-ped.gpa@mail.ru
} 
- recognition of the need to develop the axiological potential of university students in the process of professional training and insufficient theoretical and methodological development of this problem.

\subsection{The objective of the work}

The above problem is reflected in the works of many domestic and foreign authors. [1, 5, 7-11]. At the same time, in the context of the accelerating pace of modernization, higher education pays insufficient attention to the correlation and interconnection of sociocultural, educational, professional and personal values of students.

This circumstance led us to the need to study the theoretical and methodological foundations for solving the above problem $[7,5]$. Based on the study, we made theoretical conclusions that reveal the professional and personal development of university students as an axiological resource.

Of particular importance for the study of the professional and personal development of university students as an axiological resource are the following conceptual provisions:

- philosophical works that reveal the axiological aspect of a person's activity, social essence and human potential (M.S. Kagan, O.L. Kraeva etc.) $[12,7,5]$;

- sociological studies devoted to value orientations, classification of values and needs, as well as their role in socialization and self-actualization of a person (D. Bell, A. Maslow etc.) $[7,8,13,14]$;

- psychological research on the potential, activity and development of personality (B.G. Ananiev, L.S. Vygotsky, I.V. Dubrovina, K. Levin, A.N. Leontiev, V.N. Myasishchev, A.V. Petrovsky, K. Rogers, S.L. Rubinstein, D.N. Uznadze, E. Fromm, V. Frankl, E. Erickson etc.) [7, 15-17];

- the work of educational scientists related to the theory and practice of training specialists, their professional development, with the management of the pedagogical process at the university (Yu.K. Babansky, M.E. Duranov, V.I. Zhernov, O.V. Lesher, N.Ya. Saigushev, S.N. Fomina etc.) [7, 9, 18-20];

- theoretical research in the field of pedagogical axiology (V.I. Ginetsinsky, M.R. Ginzburg, I.A. Zimnyaya, A.V. Kiryakova [6, 7, 21].

The above scientific research allowed us to identify the conceptual provisions of the professional and personal development of university students as an axiological resource.

\section{Results of the research}

Achievement of the goal of our research is ensured by the consistent solution of the following tasks:

- review and analysis of pedagogical theory and practice of professional and personal development of university students as an axiological resource;

- research of the features of modern professional training of university students in the context of modernization of higher education;

- definition of the category "professional and personal development of university students";

- development of a model of the value attitude of university students to professional activities that contribute to professional and personal development.

In the context of Russia's integration into the world educational space, special requirements are imposed on higher education. According to the Federal State Educational Standard of Higher Education, students form a solid foundation of professional activity, manifested in the formed competencies. 
Personal development takes place in immersion in the wealth and diversity of relationships and manifestations of a modern person in the world. In this regard, the factors and conditions of life are important, in which the socialization of a modern university student is carried out.

For the process of professional and personal development of university students as an axiological resource, the factors known in philosophy, psychology and pedagogy as: external - objective and internal - subjective are important. Psychological and pedagogical science knows the fact that personality is the result of the interaction of objective and subjective factors. The productivity and self-realization of a person in society is due to the relationship with the inner world of the subject.

External factors - the influence of the environment, upbringing and education. In the studies of educational scientists, four main types of external factors are considered: social, socio-pedagogical, pedagogical and psychological-pedagogical. Objective factors are due to the characteristics of social development in general: economic, political, cultural, sociopedagogical. The current state of the world community, due to globalization, the development of the information society, informatization and digitalization, imposes new requirements on the modern university graduate. In the modern world, such characteristics of a professional as expertise, mobility, flexibility of thinking, self-motivation for work and continuous learning, professional development throughout life are in demand.

In modern theory and practice, the process of professional training of university students is considered from the standpoint of the following issues: satisfaction with the profession, its dynamics and factors influencing its formation; professional motivation; dynamics of the effectiveness of educational activities in the process of vocational training; professional orientation; professional competence, like readiness for professional activity $[1,7]$.

In this regard, it is necessary to focus the attention of university students on the value aspects, to reveal the significance and prospects of future professional activities, to form qualities that contribute to a consistent and conscious attitude towards the chosen profession, and readiness for professional work.

Theoretical analysis of domestic and foreign scientific literature of pedagogical theory and practice of professional and personal development of university students $[13,15,19$, $20,22]$ allows us to draw the following conclusions:

- at the heart of students' education is the awareness and acceptance of the values of the profession for a person, life, development and self-development;

- the expediency and variability of the distribution of theory and practice in teaching;

- management of professional and personal development of university students (individualization of educational routes, inclusion and active participation in additional activities of the university, in student associations, circles of professional and personal development, in project activities, in laboratories, in activities of cooperation with employers);

- providing students with the opportunity to understand the boundaries of their professional competence at the moment and help build a trajectory of professional development, taking into account individuality and the formation of the necessary competencies;

- inclusion of students in real situations of broadcasting professional culture, providing psychological and pedagogical support for professional and personal development and selfdevelopment of students, immersion in the creative professionally and personally developing environment of the university.

Internal factors - psychological, biophysical, natural inclinations and drives of a person, a set of feelings that arise under the influence of external factors. Subjective factors are due to the peculiarities of the inner world of the subject, his individuality, personality. 
The dynamism of the rate of informational development of society has led to an increase in the duration of the age of students in the higher education system from adolescence, early maturity to middle adulthood, inclusive.

Researchers E. Burns, N.V. Dubrovina, I.S. Kon, A.V. Petrovsky, E. Erickson and others $[7,13,22]$ considered the period of early maturity as favorable for the formation of responsibility, independence, the ability to actively participate in personal and social life, to constructively solve various difficult situations. At this age, the desire for intensive professional activity, the activation of thinking, resistance to stress, dedication, creative activity, and the desire for independence are expressed. Along with such a complex personal development, the professional development of university students occupies an important place. This is the age when the maturation of the personality is completed, the worldview is formed, value orientations and attitudes are formed.

Middle adulthood [7, 13, 22] is considered as a period characterized by a deep connection with professional self-realization and work activities of an adult, care for the older and younger generations, work capacity and creative activity, the dependence of intellectual abilities and activity on personal characteristics, attitudes, values, life plans. Scientists note that giftedness and education contribute to the inhibition of the involutionary process. Middle adulthood is viewed as a period of a person's heyday in work, family life, in creativity and awareness of the transience of life. Stress is a factor that reduces the health of an adult, therefore, it is important to be able to cope with non-standard situations, to be able to accept life in all its fullness and diversity, to sensibly approach phenomena and processes. Satisfaction of a person's needs for self-realization and self-esteem contributes to living this period harmoniously, in harmony with their inner world, allows you to cope with stress and maintain health. Self-concept is distinguished by self-actualization based on moral attitudes and personality rules. A person consciously refers to himself, realistically assessing himself. The integrity of the self-concept manifests itself in self-actualized individuals involved in the process of active life, providing and maintaining connections with the world in all its breadth and diversity. Labor as a leading type of activity contributes to the accumulation of experience in professional activity, the manifestation of skill and action in the role of a mentor, an authoritative leader. The stability of family and marital relations, the emergence of new responsibilities in the family, assistance to young children and elderly parents [12]. Researchers of personality development in the period of adulthood note that not everyone affords leisure self-realization, while it is very useful for a person at a given age.

Professional and personal development of university students in our study $[1,7,5]$ is considered as a process of interaction of objective and subjective factors that ensure the development of an individual's readiness for a profession on the basis of a value attitude to professional activity. In this regard, the organization of psychological and pedagogical support for the professional development of a personality is associated with the formation of a value attitude of a university student to professional activity.

We define the value attitude of students to professional activity $[7,5]$ as a stable inner conviction of a person, based on professional and moral self-awareness, the significance of which prompts to be active in mastering professional knowledge, skills and abilities. The stability of the value attitude is associated with the emotional-volitional sphere of the personality. The value attitude of students to professional activity includes a creative attitude to this activity.

Structurally, the value attitude of students to professional activity is a holistic unity of components: professional self-awareness, moral self-awareness, emotional-volitional stability and creative attitude to professional activity.

Let's take a closer look at each component. 
Professional self-awareness includes: awareness of the characteristics of future professional activity; the need for professional self-improvement, focus on professional self-development; the adequacy of self-esteem.

Professional self-awareness of a person is interconnected with moral self-awareness. The moral self-awareness of a student includes: responsibility, obligation; optimism; empathy.

The value attitude to professional activity is closely related to the emotional sphere of the individual. Thus, a student with a value-based attitude to professional activity must have a set of qualities that ensure self-regulation of his activities and an emotional state. In this regard, the next component of a student's value attitude to professional activity is emotional-volitional stability, which is revealed through: self-control, endurance; organization, composure; purposefulness, perseverance.

For the professional and personal development of a university student, it is necessary to have a creative attitude to activity, which is carried out through the creation of conditions stimulating creativity and the inclusion of students in situations that require new, nontraditional approaches.

The creative attitude to professional activity as a component of the value attitude of university students is represented by a set of characteristics: cognitive activity, independence, active life position, creative initiative.

The value-based attitude of students to professional activity activates the process of personal self-realization in the professional sphere, contributes to the professional and personal development of university students. The model of students' value attitude to professional activity, contributing to professional and personal development, includes: professional and moral self-awareness, emotional and volitional stability and creative attitude to this activity. We give a meaningful description of the model in the following sequence: structural components, functions performed.

\section{Conclusions}

The conducted review and analysis of the pedagogical theory and practice of professional and personal development of university students as an axiological resource allowed us to conclude that a person realizes the potential inherent in him throughout his life, implements a project of personality formation in the profession. Human values associated with the profession, professional activity, the sphere of application of forces and work on oneself, contribute to professional and personal development, the formation of a professional.

The study of the features of modern professional training of university students in the context of modernization of higher education showed that the interiorization of professional values of a humanistic nature creates the preconditions for the emergence of needs and motives of moral behavior, both in the professional sphere and in social life as a whole, in which the function is expressed. value orientations as a regulator of personality activity and behavior.

As a result of the study, a definition of the category of "professional and personal development of university students" was given, a model of the value attitude of university students to professional activity, contributing to professional and personal development, was developed. We give a meaningful description of the model in the following sequence: structural components, functions performed. 


\section{References}

1. E.S. Arishina, Formation of readiness of psychology students for professional activity, 179 (2012)

2. A.M. Egorychev, T.K. Rostovskaya, R.L. Kalimzhanova, The education system in the era of globalization: the need to manage its processes and trends, Youth and youth policy: new meanings and practices. Series "Demography. Sociology. Economy", 5, 1, 152-164 (2019)

3. A.M. Egorychev, L.V. Mardakhaev, V.V. Sizikova, others, Professional education in Russia: challenges, state, development directions, 352 (2019)

4. E.A. Levanova, A.V. Mudrik, others, Psychological and pedagogical problems of modern society, 298 (2018)

5. L.I. Starovoitova, E.S. Arishina, Social model of continuous professional social education, 144 (2009)

6. A.V. Kiryakova, Axiology of creativity, 232 (2019)

7. O.V. Lesher, E.S. Arishina, Development of the axiological potential of university students in the process of professional training: praxeological aspect, 102 (2009)

8. A.G. Maslow, New frontiers of human nature: Scientific, 496 (2016)

9. O.V. Lesher, A.V. Kazikin, Formation of students' creative identities in schools of higher education: structural and substantive aspects, Modern Journal of Language Teaching Methods, 6(S), 244-247 (2016)

10. E.A. Levanova, A.V. Mudrik, Psychological and pedagogical problems of modern society, 298 (2018). URL: https://znanium.com/catalog/product/1020556

11. L.I. Starovoitova, Social professional education in the modern education system, CITISE, 4 (13), 15 (2017)

12. L.I. Starovoitova, A.G. Akhtyan, E.S. Arishina, G.V. Kalabukhova, O.V. Yurchenko, Development of the social support system for the elderly in the Russian Federation as a basis for successful aging, International Journal of Applied Exercise Physiology, 9(2), 111-118 (2020)

13. V.I. Chuprov, Yu.A. Zubok, Youth in the cultural space: self-regulation of life, 304 (2020)

14. S.V. Yaremchuk, E.F. Novgorodova, Self-development and subjective well-being of modern youth, 142 (2018)

15. Yu.V. Obukhova, Modern practical psychology in providing resources for selfrealization of the individual, 305 (2016)

16. K. Rogers, Group psychotherapy, 175 (2018)

17. V. Frankl, Logotherapy and existential analysis: articles and lectures: Popular science, 344 (2016)

18. A.V. Kazikin, O.V. Lesher, O.V. Tulupova, Development of communicative creativity in masters of technical university: methodological aspect, Modern Journal of Language Teaching Methods, 7(9), 29-40 (2017)

19. S.N. Fomina, N.A. Bereza, A.A. Kvitkovskaya, Building an individual student's educational route as a way of deliberate learning activity, Uchenye zapiski of the Russian State Social University, 17, 3(148), $42-49$ (2018).

20. S.V. Yakovlev, Tutor and pupil: pedagogical interaction of value systems, 72 (2020)

21. E.S. Arishina, L.I. Starovoitova, University teacher as a subject of students' readiness formation for professional activity, Problems of modern pedagogical education, 61-4, 11-14 (2018)

22. S.V. Yaremchuk, E.F. Novgorodova, Self-development and subjective well-being of modern youth, 142 (2018) 